The idea of a photograph of a thunder wave is a pleasing fancy, at all events.

It seems to me that it will be impossible to formulate even a reasonable guess as to the cause of these dark flashes until a good many pictures are brought together for comparison, and as much testimony as possible secured as to the appearance of the flashes to the eye. Personally I have seen very few of the pictures, and never the original negative.

$\mathrm{My}$ intention in writing this letter is not so much to advance theories accounting for the phenomenon of the dark-flash as to reawaken an interest in the subject, and bring out ideas from persons qualified to treat the matter.

Madison, Wisconsin, U.S.A.

R. W. WOOD.

\section{Tides in the Bay of Fundy.}

IN the last report of Mr. W. Bell Dawson on the Survey of Tides and Currents in Canadian Waters, the results are given of an investigation of the tides in the Bay of Fundy. The information in Mr. Dawson's report is interesting, as these tides are frequently credited as having the greatest range of any in the world, and in some books of physical geography are stated as having a range of 120 feet, ${ }^{1}$ or more than double that which actually prevails.

As a matter of fact the range of the tides in the Bay of Fundy does not exceed that which occurs in the Bristol Channel, where the extreme recorded difference between high and low water at Chepstow is 53 feet, being the same as the "Saxby," or record tide in the Cumberland Basin, Nova Scotia. The rise above the mean level of the sea in both cases is about the same, or from 22 to 23 feet.

In the Bay of Fundy the range varies considerably at different localities. Outside the bay at Portland on the north side the range is $9 \frac{1}{2}$ feet, and at Cape Sable on the south side $8 \frac{1}{2}$ feet. In the Atlantic, on the south side of Nova Scotia, the range is from 6 to 7 feet. At the mouth of the bay at Yarmouth the range is 16 feet, and at Seal Island I 8 feet. Further up, at Digby, on the south side, and St. John on the north, it increases to 27 feet. Where the bay divides above Black Rock the range is 36 feet. In the Minas Basin it varies from $4 \mathrm{I}$ feet at Parsboro to 48 feet at Horton Bluff and $50 \frac{1}{2}$ feet at Noel Bay. In the Chignecto Channel in Cumberland Bay the range is $45 \frac{1}{2}$ feet.

From observations obtained by tide gauges fixed at different stations, and information collected in the localities, Mr. Dawson gives the range of spring tides as follows.

The highest recorded tide is known as the "Saxby tide," which occurred in 1869. The low water mark for that tide is not given, but taking the lowest low water level recorded, the range of that tide in Cumberland Bay was 52.80 feet; the ordinary spring tide range there being 45.80 feet. The Admiralty tide tables give this as $45 \frac{1}{4}$ feet.

At Moncton, the Saxby tide rose above the lowest recorded level, 38.34 feet; the next highest recorded tide being in 1887 , $3 \mathrm{I} 9 \mathrm{I}$ feet. An ordinary spring tide rises $30^{\circ} 25$ feet above mean low water of spring tides. The Admiralty tide tables give the range at Moncton Railway as 47 feet. Mr. Dawson points out that this is misleading, this range being that above low water at the mouth of the river, from which the low water line has a considerable inclination towards the head of the estuary.

At Parsboro, in the Minas Basin, the ordinary spring tide range is $4 \mathrm{I}$ feet, and the extreme 47 feet; the Admiralty tide tables giving the ordinary range as 43 feet.

Mr. Murphy, the Provincial Engineer of Nova Scotia, in a paper contributed in 1867 to the Institute of Natural Science, on the tides in the Bay of Fundy, gave the range of spring tides at the head of the bay as 22 feet above mean sea level, and as varying from 50 to 60 feet above extreme low water.

Having a few years since to report on some proposed embankment works in the Bay of Minas, I made inquiries in the locality from those best able to furnish me with information as

IIn Sir J. F. Herschell's "Physical Geography of the Earth," fifth edition, 1875 , it is stated that: "In the Bay of Fundy the tide not uncommonly rises $5^{\circ}$ feet, and, as is said, on some occasions to more than double Tides, says, "In the Bay of Fundy, in the harbour of Annapolis Royal the tide rises rzo feet.'

NO. I 559 , VOL. 60] to the rise of the tides there, and came to the conclusion that at Horton the greatest range to be dealt with was 48.50 feet.

The difference in the range of the tides in Cumberland Bay, at the head of the Bay of Fundy, and in Verte Bay, North. umberland Straits, in the Gulf of St. Lawrence, is worth recording. The length of the isthmus which separates the two bays along the line of the proposed Chignecto Ship Railway is eighteen miles. The range of ordinary spring tides on the one side of this neck of land is $45^{\circ} 80$ feet, and of the highest known tide 52.80 feet; and on the other side 13.40 feet and 5.60 feet respectively, the mean level of the sea being only 0.26 feet higher in the Cumberland Bay than in Bay Verte.

It is interesting to compare the tides in the Bay of Fundy with those in the Bristol Channel. At Bude Haven and Pem. broke, at the mouth of the Channel, the rise of an ordinary spring tide is 23 feet; at the mouth of the Avon it is 40 feet at Chepstow the range is 50 feet, and in extreme tides 53 feet, the rise above the mean level of the sea being $23 \frac{1}{2}$ feet. From levels taken across the land from Portishead in the Bristol Channel to Axmouth in the English Channel, with a mean tide rising $35 \frac{1}{2}$ feet at Portishead and Io feet at Axmouth, the mean level of the sea was found to be 9 inches higher at the former than at the latter place. ${ }^{1}$

There is a tidal bore in the Bay of Fundy, but it is not so strongly developed as at some other places. It shows itself at Moncton, I9 miles from the mouth of the Petticodiac River, where the estuary consists, at low tide, of mud banks and flats, with a low water channel about 500 feet wide, and having at high water a width of half a mile. The run of the rising tide first breaks into a bore at Stoney Creek, 8 miles below Moncton, and continues to the head of the estuary at Salisbury, I3 miles above, the total distance traversed being $2 \mathrm{I}$ miles. Mr. Dawson describes the noise made by the approaching bore as that of a distant train, which increased to the hissing and rushing sound of broken water. The bore arrived at the point of observation eleven minutes after the sound was first heard, having the appearance of a front of broken and foaming water 2 to 3 feet in height. The mean velocity was 8.47 miles an hour, the maximum being 9.6I miles. The greatest rise of water after the bore passed was 3 feet in ten minutes. The greatest recorded height of the bore is 5 feet 4 inches.

The only other place in the bay in which a bore has been observed is in the upper part of Cobequid Bay.

W. H. WHEELER.

\section{ETHNOGRAPHICAL COLLECTIONS IN GERMANY.}

THE question of the representation of primitive culture in our national museums is rapidly becoming an urgent one, not only on account of the growing importance of anthropology, but also because primitive culture itself is disappearing before civilisation. The wild man is dying out or being transformed, and the hours during which we may question him about himself are already limited. Those nations therefore which take the utmost advantage of the opportunities which remain will have something in the nature of a monopoly when primitive culture is actually extinct ; and it is to them that the students of the twentieth century will have to apply for their facts.

If her present rate of progress is maintained, Germany will soon have so far distanced all other European countries as to place herself in a position of permanent and unassailable superiority. It cannot therefore but be a matter of importance to cast a glance at the present state of ethnographical museums in Germany, in order that we may form some notion of the relative position of our own.

Almost all the large cities in the German Empire possess ethnographical collections, and in such places as Leipzig, Dresden and Hamburg, these are of first-rate

\section{1 “Tidal Rivers." (Longman's Engineering Series, 1893.)}


importance. But none of them are in the same class with Berlin, and as it is with Berlin that London ought to measure itself, these short remarks must practically be confined to the German capital.

The Königliches Museum für Völkerkunde is a large building completely devoted to ethnographical and prehistorical collections: it has three floors, the lowest devoted to prehistory; the first to the collections from Africa, Oceania and America; the second to those from Asia. For administrative purposes it is divided into five departments: the Prehistoric, the African and Oceanic, the American, the Indian, and the Chino-Japanese. Each of these departments has a keeper, who usually has two assistants under him, so that the scientific staff amounts to about twelve men. The museum has an annual grant of 50,000 marks, which is supplemented upon special occasions by the voluntary gifts of a committee of wealthy and patriotic citizens known as the "Hilfskomitée." The value of this unofficial assistance can hardly be over-estimated. It makes possible the acquisition of exceptionally fine collections when the Government grant is not alone sufficient, as in the case of Benin, and it provides the means of retaining scientific explorers and collectors in outlying parts of the world. The museum can thus command the services of wellinstructed investigators, and is in a position to carry out the work of collecting in a systematic and continuous manner. Berlin is probably far less dependent on the dealer and the unscientific collector than we are in London. Altogether the Hilfskomitée appears to be a most admirable institution reflecting the greatest possible credit upon all concerned.

The housing of the collections at the Museum fuir Völkerkunde is also excellent. In addition to extensive basements and a domed hall with a gallery running round it, there are two large and four smaller rooms on each of the three floors. Most of these are lighted from both sides, the objects being exhibited in large free-standing metal cases with glass shelves, so that none of the specimens lie in deep shadow. The wall space between the windows and at the ends of the rooms is thus available for maps and diagrams, of which there are great numbers ; there is also room for numerous "mannikins," or lifesized models of representatives of various tribes, all carefully coloured, and dressed and armed in the style of their respective countries. These figures, with excellent models of houses, canoes and other large objects, and with ample and carefully written labels, afford a far more vivid picture of primitive life than can be obtained from books alone. The arrangement of the collections is geographical, but occasionally comparative series, known as "Vergleichende Gruppen," are exhibited; this is especially the case in the Indian Section. A library and a lecture theatre are important adjuncts to the building, and the latter brings the museum into direct connection with anthropological teaching. This has obvious advantages, for it probably enables the staff to stimulate the interest in ethnology of many students who afterwards become connected with Colonial administration.

Enough has perhaps been said to illustrate the advantages which Germany enjoys in the acquisition of ethnographical collections and in the dissemination of ethnological knowledge. Compared with our own, her position is very striking. We have no independent ethnographical museum, for at present we can only use for the purpose a section of the Department of British and mediaval antiquities at the British Museum. The officials of this Department, with so many other claims upon their attention, cannot be expected to compete with the organised staff at Berlin, who concentrate their whole attention on ethnographical studies. $A$ gainst continuous and systematic collection we can only set occasional and limited acquisitions. Under such con- ditions, the race between Great Britain and Germany is a race between Argus and a blind man. Nor can we flatter ourselves that we are to be eclipsed by Berlin alone; for Leipzig is already a serious rival, and Dresden is considering the erection of a new museum of ethnography. In numerous other towns there are abundant signs of activity.

If it is asked how it is that the Germans have outstripped us in this manner, several reasons at once suggest themselves. To begin with, the rapid commercial and Colonial expansion of Germany during the last thirty years has been the expansion of the best educated people in Europe. Thus there has been little tendency to regard savage races from the point of view of a popular show, and a widespread capacity to assign to primitive culture its due scientific importance. If this is the attitude of the people as a whole, it is but natural that in officials, travellers and merchants a taste for ethnology is easily awakened. And as these are the classes in which a museum would naturally find its most useful allies, the national collections have greatly benefited by their interest and co-operation. The introduction to the Guide to the Museum für Völkerkunde contains a large proportion of official names in its long list of donors. Naval and military officers, consuls, doctors and administrators, are all conspicuous in their turn. The museum has also enjoyed the support of more exalted personages, for the German Emperors have all given proof of their sympathy upon various occasions. Again, the German museums appear in many respects to be worked more economically than our own. Their hours of closing are early, so that artificial lighting is not required in the galleries ; they are also closed during at least one day in each week, which enables scientific studies to be carried on with the minimum of interruption, and the work of cleaning to be executed by a smaller staff. The fittings are also arranged with less regard for high finish than for practical and serviceable qualities. Finally, the wonderful energy and initiative of the veteran Prof. Bastian must not be forgotten. $\mathrm{He}$ has pressed the claims of ethnography with untiring enthusiasm for many years, and bas had the reward of living to see the museum which he directs take the first place among the ethnographical museums of the world.

Comparisons are proverbially odious, and that which one is compelled to draw between Berlin and London is not gratifying to national pride. It is hard to believe that we can continue satisfied with present con. ditions, and sooner or later a change must come. Let all scientific men, whether their immediate interests lie in the direction of ethnography or not, lend their sympathy and support to any movement which promises to introduce a new order of things. But the old order must be changed quickly, or it may be too late. Even now it is doubtful whether we can ever make up all the ground which has been lost, for in some parts of the world specinens of primitive art are vanishing with such rapidity that complete collections are perhaps unattainable. But a serious effort made at the present time would be crowned at least with a comparative success; and the first thing to be done is to house in a more satisfactory manner what we already possess. It would surely be desirable to unite under one roof the collections which illustrate primitive culture, and those which illustrate the physical characteristics of the different branches of mankind. Meanwhile it should be freely admitted that we have much to learn from continental nations, for not only Germany but also Holland can give us useful lessons in the ethnographical exploitation of a Colonial Empire. But Berlin is the model which we should set before our eyes: the frank admission of this fact will be the best preliminary to a more satisfactory state of affairs.

NO. I 559 , VOL. 60] 